\title{
Monocytes give rise to mucosal, but not splenic, conventional dendritic cells
}

\author{
Chen Varol, ${ }^{1}$ Limor Landsman, ${ }^{1}$ Darin K. Fogg, ${ }^{3}$ Liat Greenshtein, ${ }^{1}$ \\ Boaz Gildor, ${ }^{1}$ Raanan Margalit, ${ }^{1}$ Vyacheslav Kalchenko, ${ }^{2}$ \\ Frederic Geissmann, ${ }^{3}$ and Steffen Jung ${ }^{1}$
}

'Department of Immunology and ${ }^{2}$ Department of Veterinary Resources, The Weizmann Institute of Science, 76100 Rehovot, Israel

${ }^{3}$ Institut National de la Santé et de la Recherche Médicale (INSERM), Laboratory of Mononuclear Phagocyte Biology, Necker Enfants Malades Institute, and University of Paris Rene Descartes Medical School, Necker Enfants Malades Hospital, 75015 Paris, France

The mononuclear phagocyte (MP) system is a body-wide macrophage (MФ) and dendritic cell (DC) network, which contributes to tissue homeostasis, inflammation, and immune defense. The in vivo origins of MPs remain poorly understood. Here, we use an adoptive precursor cell transfer strategy into MP-depleted mice to establish the in vivo differentiation sequence from a recently identified $\mathrm{M \Phi /DC-restricted} \mathrm{bone} \mathrm{marrow} \mathrm{(BM)} \mathrm{precursor}$ (MDP) via BM and blood intermediates to peripheral MФs and DCs. We show that MDPs are in vivo precursors of BM and blood monocytes. Interestingly, grafted Gr 1 high "inflammatory" blood monocytes shuttle back to the BM in the absence of inflammation, convert into Gr $1^{\text {low }}$ monocytes, and contribute further to MP generation. The grafted monocytes give rise to DCs in the intestinal lamina propria and lung, but not to conventional CD11 $\mathrm{c}^{\text {high }}$ DCs in the spleen, which develop during homeostasis from MDPs without a monocytic intermediate.

CORRESPONDENCE

Steffen Jung:

s.jung@weizmann.ac.il

Abbreviations used: DTR, diphtheria toxin receptor; DTx, diphtheria toxin; IBC, intra bone cavity; lp, lamina propria; MDP, M $\Phi / D C$ precursor; $\mathrm{MP}$, mononuclear phagocyte; $M \Phi$, macrophage.
Historically, the body-wide cellular network of peripheral mononuclear phagocytes (MPs) has been subdivided into macrophages (MФs) and DCs, which were discovered toward the end of the 19th century and in the 1970s, respectively $(1,2)$. Both $M \Phi$ s and DCs consist of multiple subpopulations largely defined by distinct anatomic location and phenotypes. $M \Phi_{\mathrm{s}}$ include representatives in the serosa, lamina propria (lp), lung, brain (microglia), bone (osteoclasts), and liver (Kupffer cells; reference 3). DCs, on the other hand, have been divided into epidermal Langerhans cells, plasmacytoid DCs, and conventional CD11 $c^{\text {high }}$ DCs, which in mice are themselves composed of three subsets $\left(\mathrm{CD}^{+}{ }^{+} \mathrm{CD}^{-}, \mathrm{CD}^{-}{ }^{-} \mathrm{CD} 8^{-}\right.$, and $\mathrm{CD}_{4}^{-}$ $\mathrm{CD}^{+}$; reference 4). MPs are involved in tissue remodeling and homeostasis, as well as regulatory and stimulatory aspects of innate and adaptive immunity.

MPs arise from mesoderm-derived hematopoietic precursor cells, which in mammals are generated in two independent temporally and spatially separated waves (5). "Definitive"

$\overline{\text { The online version of this article contains supplemental material. }}$ intra-embryonic hematopoiesis results in the generation of multipotent hematopoietic stem cells that eventually seed the BM. Certain MP populations, such as the brain microglia and epidermal Langerhans cells, are capable of selfrenewal or are derived from tissue-resident precursors $(6,7)$. However, most other peripheral MP subsets of the adult, particularly the short-lived CD11 $\mathrm{c}^{\text {high }}$ DC (8), are believed to rely on continuous replenishment from the BM-resident hematopoietic stem cells. The hematopoietic stem cell differentiation pathway into MPs includes several BM intermediates, such as the common myeloid precursors (9), granulocyte/M $\Phi$ precursors (9), and $M \Phi /$ DC precursors (MDPs; reference 10), characterized by their progressive loss of ability to give rise to other hematopoietic cell types.

Systemic dissemination into the peripheral MP pool is thought to be ensured by circulating blood monocytes (11). Human monocytes are long known to consist of discrete subpopulations (12), and, more recently, monocyte heterogeneity has also been established in the mouse (13-16) and rat (17). Circulating murine monocytes comprise two main subsets: Gr $1^{\text {high }}$ 
$\mathrm{CX}_{3} \mathrm{CR} 1^{\text {int }} \mathrm{CD}_{62} \mathrm{~L}^{+} \mathrm{CCR} 2^{+}$and $\mathrm{Gr} 1^{\text {low }} \mathrm{CX}_{3} \mathrm{CR} 1^{\text {high }} \mathrm{CCR} 2^{-}$. $\mathrm{Gr} 1$ high "inflammatory" monocytes were shown to home preferentially to sites of inflammation, whereas Gr1 ${ }^{\text {low }}$ monocytes are believed to seed resting tissues in the steady state (15). However, the origin and biology of this intriguing short-lived leukocyte, which cannot be generated in vitro, remain poorly understood.

Here, we report the use of adoptive precursor transfer experiments in WT and $\mathrm{MP}$-depleted recipient mice to study the origin, interrelation, and differentiation potential of murine BM and blood monocytes. Using intra bone cavity (IBC) transfer we establish the in vivo differentiation sequence from the recently reported MDP (10) to BM and blood monocytes and terminally differentiated peripheral MPs. Interestingly, monocytes appear to be dedicated to DC replenishment of nonlymphoid organs, such as the intestinal lp and the lung, whereas splenic DCs seem to arise from local precursors without a monocytic intermediate. Furthermore, we show that in the absence of inflammation, the Gr1 high blood monocyte subset efficiently shuttles back to the BM, converts into Gr1 $1^{\text {low }}$ monocytes, and thus contributes further to MP generation.

\section{RESULTS}

MDPs give rise to $\mathrm{BM}$ and blood monocytes

Taking advantage of a mouse strain that carries a replacement of the $\mathrm{CX}_{3} \mathrm{CR} 1$ chemokine receptor gene by a GFP reporter $\left(\mathrm{CX}_{3} \mathrm{CR} 1^{\mathrm{gfp}}\right.$ mice; reference 18$)$, we recently reported the isolation of a novel proliferating clonogenic precursor (termed MDP) from murine BM that gives rise exclusively to $M \Phi_{\mathrm{S}}$ and DCs. When injected into the blood stream of recipient mice, MDPs expand and differentiate into splenic $M \Phi_{\mathrm{s}}$ and DCs (10). In this study, we sought to study the potential of MDPs to differentiate within their native BM microenvironment and give rise to BM and blood monocytes. We therefore revised our original adoptive MDP transfer approach by injecting the MDPs into the BM, i.e., the femoral bone cavity, of the recipient mice.

The BM of $\mathrm{CX}_{3} \mathrm{CR} 1^{\text {gfp }}$ donor mice contains three main distinct $\mathrm{CD}_{115^{+}} \mathrm{CX}_{3} \mathrm{CR} 1 / \mathrm{GFP}^{+}$populations: $\mathrm{CD} 117^{+}$ $\mathrm{CD}_{11 b^{-}} \mathrm{Gr}^{-}$cells (Fig. $1 \mathrm{~A}$ ), which represent dedicated MDPs (GFPlow; reference 10), and two discrete Gr1(Ly6C/G) ${ }^{\text {high }}$ and $\mathrm{Gr} 1(\mathrm{Ly} 6 \mathrm{C} / \mathrm{G})^{\text {low }}$ subsets of $\mathrm{CD} 11 \mathrm{~b}^{+} \mathrm{BM}$ monocytes (19) that in $\mathrm{CX}_{3} \mathrm{CR} 1^{\text {gfp }}$ mice appear as GFPint and GFPhigh, respectively (Fig. $1 \mathrm{~A}$ ). To study the interrelation of these populations, we isolated BM from heterozygote mutant $\mathrm{CX}_{3} \mathrm{CR} 1^{\text {gfp }}$ donor mice (CD45.1) and sorted MDPs to purity according to surface CD117 (cKit) and GFP expression, as well as the absence of CD11b and Gr1 markers (Fig. 1 B). MDPs were then injected into the right femoral bone cavity of unmanipulated WT mice (CD45.2). The recipient mice were killed at various time points after adoptive transfer and subjected to flow cytometry analysis of blood and BM. The differential allotypic CD45 marker of host and graft, in addition to the GFP label of the $\mathrm{CX}_{3} \mathrm{CR} 1^{\text {gfp }}$ cells, allowed detection of the graft. Analysis of the recipient BM at days 3 and 6
A $\mathrm{CX}_{3} \mathrm{CR} 1^{\text {gfp }} \mathrm{BM}$ (donor)

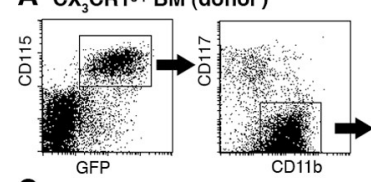

$\mathrm{C}_{\text {Recipient BM (right) }}$

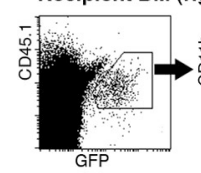

D
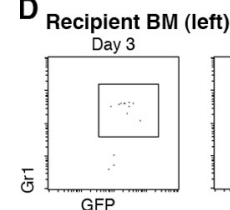

GFP
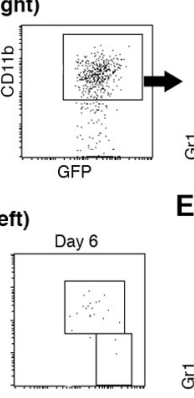

E

$E_{\text {Recipient blood }}$

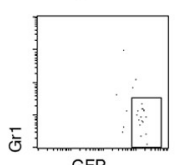

Figure 1. Characterization of $\mathrm{CX}_{3} \mathrm{CR} 1^{\mathrm{gfp}} \mathrm{BM}$ and IBC transfer of MDPs. (A) Flow cytometry analysis of $\mathrm{CX}_{3} \mathrm{CR}{ }^{\mathrm{gfp} /+} \mathrm{BM}$. The cells in the dot plots to the right are gated according to CD115 and GFP expression. Note the presence of three main $\mathrm{CD}_{11} 5^{+} \mathrm{GFP}+$ populations:

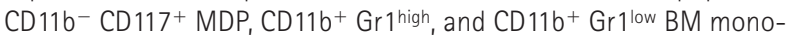
cytes. (B) Flow cytometry analysis of an MDP graft isolated by high speed sorting according to CD117 and GFP expression. (C) Analysis of WT recipient BM (right, injected femur) at the indicated time points after IBC transfer of $2.5 \times 10^{4} \mathrm{MDPs}$ (purity: $85 \%$, devoid of Gr $1^{\text {high }}$ $\mathrm{CD}_{11 b^{+}}$cells). Note the distinct GFP intensity pattern of differentiated graft-derived $\left(\mathrm{CD} 45.1^{+}\right) \mathrm{CD} 11 \mathrm{~b}^{+} \mathrm{Gr} 1^{\text {high }}$ and $\mathrm{Gr} 1^{\text {low }} \mathrm{BM}$ monocytes and the decrease in the Gr1 $1^{\text {high }} / \mathrm{Gr} 1^{\text {low }}$ ratio with time: 14 (day 3) to 2.7 (day 6). (D) Analysis of WT recipient BM (left, noninjected femur) at the indicated time points after IBC transfer. Gating as in C. (E) Analysis of recipient blood (day 6). The cells were gated according to CD115 surface marker expression. The data are representative of at least two independent experiments per time point.

after transfer revealed the presence of $\mathrm{GFP}^{+} \mathrm{CD} 45.1^{+}$cells expressing the surface marker CD11b (Fig. 1 C). As in the donor mice, $\mathrm{CD} 11 \mathrm{~b}^{+} \mathrm{GFP}^{+}$cells could be further subdivided according to $\mathrm{Gr} 1$ and $\mathrm{CX}_{3} \mathrm{CR} 1 / \mathrm{GFP}$ expression (Fig. $1 \mathrm{C}$ ). Interestingly, Gr1 $1^{\text {high }}$ cells, and to a lesser extent $\mathrm{Gr} 1^{\text {low }}$ graftderived cells, were detected also in the noninjected (left) recipient femur (Fig. 1 D). Analysis of the blood revealed the presence of $\mathrm{GFP}^{+}$graft-derived monocytes that were largely Gr1 $1^{\text {low }}$ (day 6; Fig. 1 E). These findings show that upon IBC transfer, MDPs are able to differentiate into both Gr1 $1^{\text {high }}$ and Gr1 $1^{\text {low }}$ BM monocytes. Given the small number of transferred MDPs $\left(2.5 \times 10^{4}\right.$ cells $)$, this sequence likely involved proliferative expansion of the graft. To investigate the interrelation between the two BM monocyte subsets, we next isolated $\mathrm{CD}_{11} \mathrm{~b}^{+} \mathrm{Gr} 1^{\text {high }} \mathrm{GFP}$ int $\mathrm{BM}$ monocytes from the BM of $\mathrm{CX}_{3}$ CR1 ${ }^{\text {gfp }}$ mice (CD45.1; Fig. $2 \mathrm{~A}$ ) and performed an IBC transfer. Analysis of recipient mice days 1 and 3 after transfer revealed the presence of graft-derived Gr1 ${ }^{\text {low }}$ GFP high BM monocytes (Fig. 2 B). These findings suggest that $\mathrm{Gr} 1^{\text {high }}$ $\mathrm{BM}$ monocytes can serve as in vivo precursors of $\mathrm{Gr} 1^{\text {low }} \mathrm{BM}$ monocytes, as has been reported for $\mathrm{Gr} 1^{\text {high }}$ blood monocytes $(16,20)$. It bears mention that at both time points, graftderived monocytes were again detected in the noninjected 


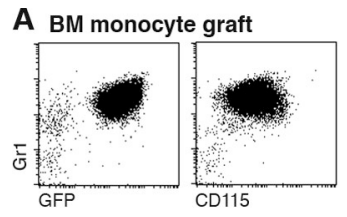

B Recipient BM (right)

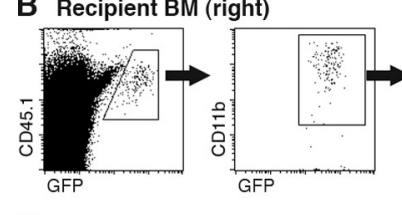

C Recipient BM (left)

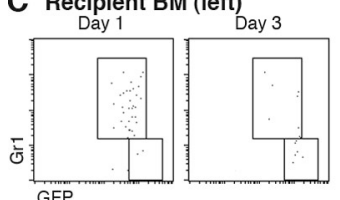

Figure 2. IBC transfer of BM monocytes. (A) Flow cytometry analysis of $\mathrm{Gr} 1^{\text {high }} \mathrm{BM}$ monocyte graft. (B) Analysis of WT recipient BM (right, injected femur) at the indicated time points after IBC transfer of $5 \times 10^{5}$ Gr $1^{\text {high }}$ BM monocytes (purity: 90\%). Note the distinct GFP intensity pattern of differentiated graft-derived $\left(\mathrm{CD} 45.1^{+}\right) \mathrm{CD} 11 \mathrm{~b}^{+} \mathrm{Gr} 1^{\text {high }}$ and $\mathrm{Gr} 1^{\text {low }}$ cells and the decrease in the $\mathrm{Gr} 1^{\text {high }} / \mathrm{Gr} 1^{\text {low }}$ ratio with time: 5 (day 1 ) to 1.8 (day 3). (C) Analysis of WT recipient BM (left, noninjected femur) at the indicated time points after IBC transfer. Gating as in C. The data are representative of at least two independent experiments per time point. (D) Analysis of recipient blood (day 3 ). Note the sizeable presence of graft-derived $\left(\mathrm{CD} 45.1^{+}\right) \mathrm{CD}_{11 b^{+}} \mathrm{Gr} 1^{\text {low }}$ monocytes.

femura of the recipient mice (Fig. 2 C). Recipient mice also exhibited a prominent population of Gr1 low blood monocytes, supporting the notion that the grafted Gr1 ${ }^{\text {high }}$ cells had differentiated (Fig. 2 D). Collectively, IBC transfer of MDP and $\mathrm{BM}$ monocytes recapitulated the sequential in vivo differentiation of MDPs, Gr1 $1^{\text {high }}$ BM monocytes, Gr1 ${ }^{\text {low }} \mathrm{BM}$ monocytes, and Gr1 $1^{\text {low }}$ blood monocytes.

\section{Gr $1^{\text {high }}$ inflammatory monocytes shuttle between the blood and BM}

The detection of graft-derived BM monocytes in the noninjected femur after the IBC transfer of MDPs and BM monocytes (Figs. $1 \mathrm{D}$ and $2 \mathrm{C}$ ) suggested that grafted cells or their descendants had entered the circulation and shuttled between bone cavities. Furthermore, the rare graft-derived cells in the noninjected femura were mainly of the Gr1 high phenotype. We previously reported that homing of the Gr1 ${ }^{\text {high }} \mathrm{CD} 62 \mathrm{~L}^{+}$ $\mathrm{CCR}^{+}$monocyte subset was restricted to sites of inflammation. In the absence of the latter, adoptively transferred $\mathrm{Gr} 1^{\text {high }}$ blood monocytes, but not Gr1 ${ }^{\text {low }}$ blood monocytes, rapidly disappeared from the circulation of recipient mice (15). Our present results raised the possibility that this observation might have been due to the immediate and quantitative recruitment of the Gr1 $1^{\text {high }}$ blood monocytes to the recipient BM. To investigate this issue, we adoptively transferred Gr1 high blood monocytes isolated by MACS from $\mathrm{Rag}^{-/-}$ $\mathrm{CX}_{3} \mathrm{CR} 1^{\text {gfp }}$ mice (Fig. $3 \mathrm{~A}$ ) to the circulation of WT recipients.
Analysis of the recipient mice on day 4 revealed the abundant presence of grafted $\mathrm{GFP}^{+}$cells in the recipient BM (Fig. 3 B), which were $\mathrm{Gr} 1^{\text {high }}$ and $\mathrm{Gr} 1^{\text {low }}$ (not depicted). In contrast and as previously reported (15), we failed to detect Gr1 $1^{\text {high }}$ monocytes in the recipient blood, although it contained a sizeable population of $\mathrm{Gr}^{\text {low }}$ monocytes (Fig. $3 \mathrm{~B}$ ). This indicates that in the absence of inflammation, Gr1 ${ }^{\text {high }}$ blood monocytes efficiently shuttle from the blood to the BM. These data also directly support the notion that $\mathrm{Gr} 1^{\text {high }}$ blood monocytes are in vivo precursors of $\mathrm{Gr} 1^{\text {low }}$ monocytes $(16,20)$. To further substantiate this point, we i.v. transferred Gr1 ${ }^{\text {high }}$ BM monocytes into recipient mice. Like the Gr1 ${ }^{\text {high }}$ blood monocytes, these cells rapidly homed to the recipient BM. Day 1 after transfer, graft-derived monocytes were mainly $\mathrm{Gr} 1^{\text {high }}$ in both the BM and blood compartments, whereas at day 3, the grafted cells had almost quantitatively converted into Gr1 low monocytes (Fig. $3 \mathrm{C}$ and Table I). To confirm the BM homing of the i.v. injected Gr1 $1^{\text {high }}$ BM monocytes, we performed whole body optical imaging using the near-infrared lipophilic carbocyanine tracer DiR (21). Although most transferred DiR-labeled monocytes accumulated in the lung, liver, and spleen, grafted cells were also readily detectable in the BM (femora and cranium) of the recipient mice (Fig. 4, A-C). Independent intravital experiments with CFSE-labeled grafts suggested that Gr1 $1^{\text {high }}$ monocytes had indeed extravasated and entered the cranial BM parenchyma (Fig. 4 D). These results show that Gr1 high monocytes efficiently home to the BM. However, unlike senescent neutrophils that return to the BM to die (22), Gr1 $1^{\text {high }}$ monocytes recycle, differentiate into $\mathrm{Gr} 1^{\text {low }}$ monocytes, and can return to the blood to further contribute to the peripheral MP pool.

Table I. Distribution of adoptively transferred $\mathrm{Gr} 1^{\text {high }}$ $\mathrm{BM}$ monocyte grafts in the BM and blood compartment of recipient mice

\begin{tabular}{lccc}
\hline & $\begin{array}{c}\text { Total no. CD115 } \\
\text { cells }\end{array}$ & $\begin{array}{c}\text { \% graft-derived } \\
\text { CD115 } 5^{+} \text {cells }\end{array}$ & $\begin{array}{c}\text { No. graft-derived } \\
\text { CD115 }\end{array}$ \\
\hline Day 1 & & & \\
Blood & $1.6 \times 10^{5 a}$ & $1.6( \pm 0.15)$ & $2.6 \times 10^{3}$ \\
BM & $5 \times 10^{7 b}$ & $0.17( \pm 0.01)$ & $8.5 \times 10^{4}$ \\
Day 3 & & $0.6( \pm 0.13)$ & $10^{3}$ \\
Blood & $0.05( \pm 0.01)$ & $2.3 \times 10^{4}$ \\
BM & & \\
Day 6 & & $0.15( \pm 0.03)$ & 240 \\
Blood & & $0.033( \pm 0.005)$ & $1.6 \times 10^{4}$ \\
BM & &
\end{tabular}

WT recipients of $\mathrm{Gr}$ 1 $^{\text {high }} \mathrm{BM}$ monocytes ( $5 \times 10^{5}$ cells; purity: $96 \%$ ) were analyzed by flow cytometry on days 1, 3, and 6 after i.v. transfer. Data correlate to Fig. 3 C. Note that according to our calculation day 1 after transfer, a total of 17\% of the grafted monocytes can be found in the recipient BM, whereas $0.52 \%$ of the cells are circulating in the recipient blood.

aBased on mouse phenome database (http://phenome.jax.org/pub-cgi/phenome/ mpdcgi?rtn=docs/home).

${ }^{\circ}$ Based on reference 55 . The percentage of $C D 115^{+}$cells of nucleated BM cells was determined to be $12 \%$ by flow cytometric analysis (not depicted). 
Collectively, our results suggest that Gr1 $1^{\text {high }} \mathrm{BM}$ and blood monocyte populations are linked. To investigate a potential functional overlap between these two populations, we tested Gr1 high BM monocytes for a hallmark of their blood counterpart, e.g., the recruitment to sites of inflammation $(13,15,23)$. Highlighting the dual homing potential of i.v. injected Gr1 $1^{\text {high }} \mathrm{BM}$ monocytes, thioglycollate-induced inflammation caused the grafted cells to deviate from their

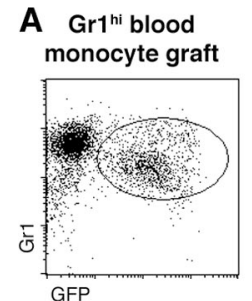

C
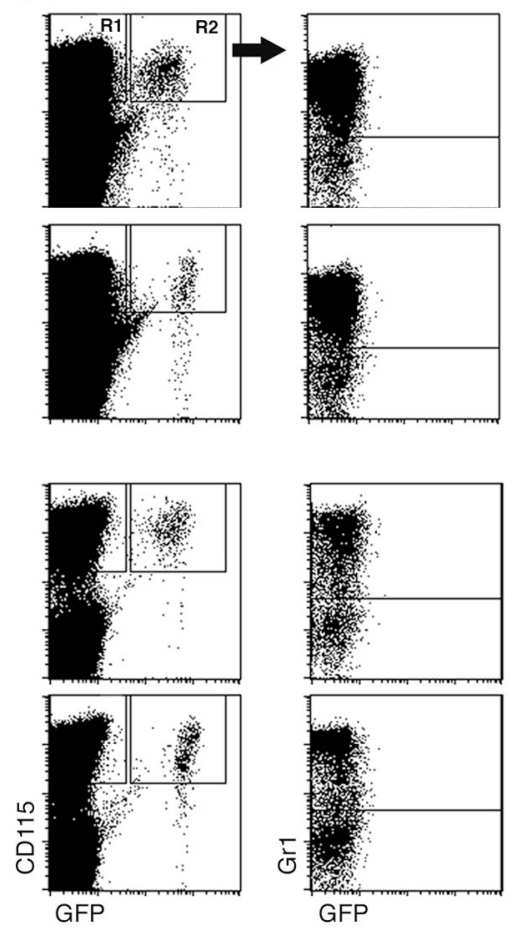

GFP

B Recipient BM

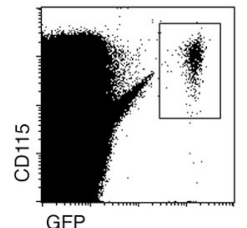

Recipient (R1)
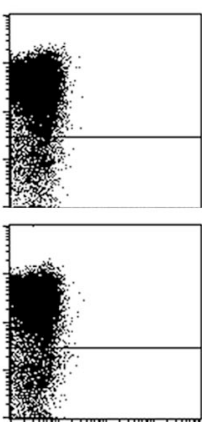

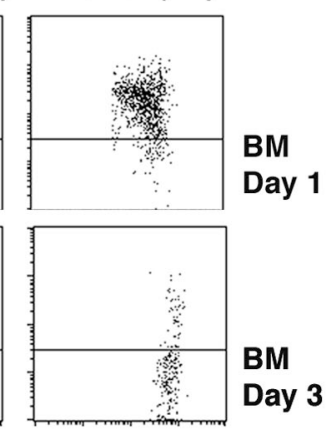

BM

Day 1
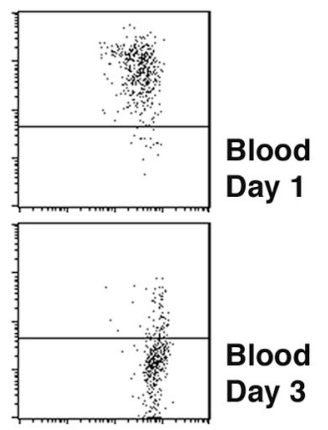

Day 3

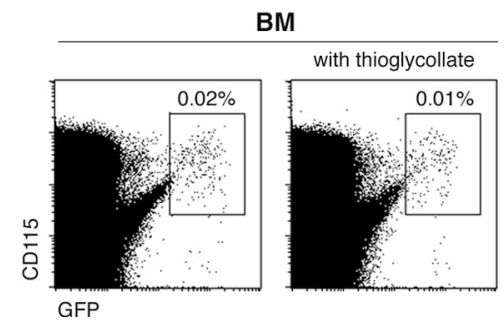

Day 1
D Peritoneal cavity
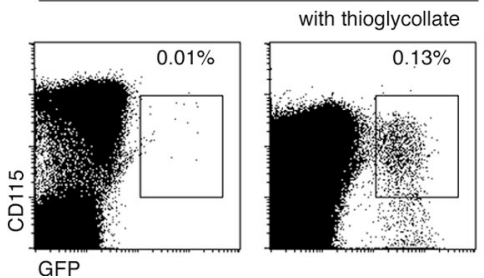

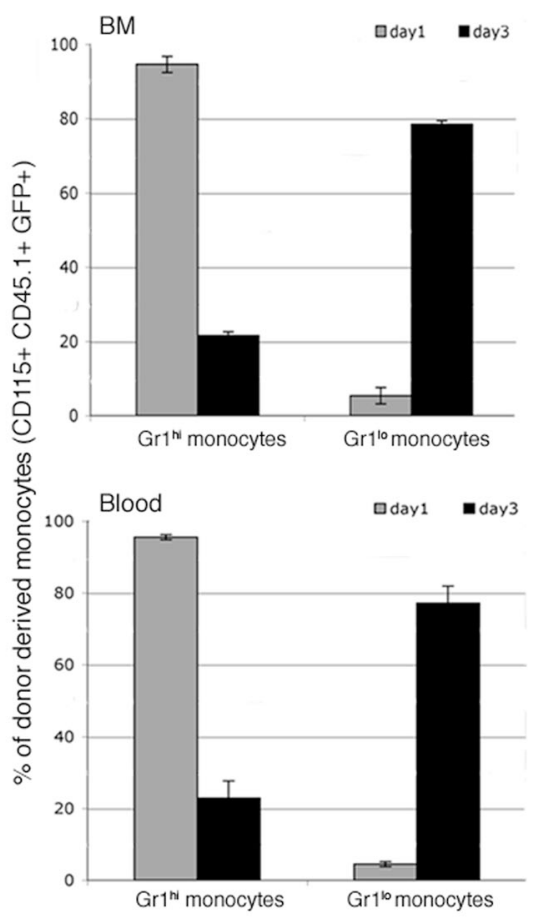

Figure 3. Gr1 ${ }^{\text {high }}$ blood and BM monocytes shuttle between blood and BM. (A) Flow cytometry analysis of a blood monocyte graft isolated from $\mathrm{Rag}^{-1-} \mathrm{CX}_{3} \mathrm{CR} 1$ gfp mice. The GFP- cells are $\mathrm{Ly}_{6 \mathrm{G}}{ }^{+} \mathrm{CX}_{3} \mathrm{CR}^{-}$- granulocytes (reference 18). (B) Analysis of recipient BM and blood $4 \mathrm{~d}$ after adoptive cell transfer of $\mathrm{Gr} 1^{\text {high }}$ blood monocytes $\left(10^{5}\right.$ cells). Note the presence of graft-derived (GFP+) $\mathrm{Gr}^{\text {low }}$ monocytes in the blood. Fractions of graft-derived $\mathrm{GFP}^{+}$cells of total $\mathrm{CD} 115^{+}$cells in recipient BM $(0.12 \%)$ and in recipient blood (0.76\%). (C) Analysis of BM and blood of WT recipients of Gr 1 $^{\text {high }} \mathrm{BM}$ monocytes $\left(5 \times 10^{5}\right.$ cells; purity: $\left.96 \%\right)$ days 1 and 3 after i.v. transfer. Note the loss of $\mathrm{Ly} 6 \mathrm{C} / \mathrm{G}$ expression on grafted $\mathrm{Gr} 1^{\text {high }}$
BM monocytes. Bar diagrams summarize data obtained from three mice per time point. Note the difference of GFP intensity of BM and blood monocytes on day 1 (mean fluorescence intensity: $274.75 \pm 13.9$ vs. $376.6 \pm 20.5 ; P=0.003)$. (D) Flow cytometry analysis of BM and peritoneal cavity (PC) lavage of WT recipients of MACS-purified CD $115^{+}$ BM monocytes ( $10^{6}$ cells; purity: $88 \%$ ) that were left untreated or had been inoculated with thioglycollate. Note the recruitment of grafted $\mathrm{Gr} 1^{\text {high }} \mathrm{BM}$ monocytes to the inflamed peritoneal cavity. The data are representative of at least two independent experiments per time point. 

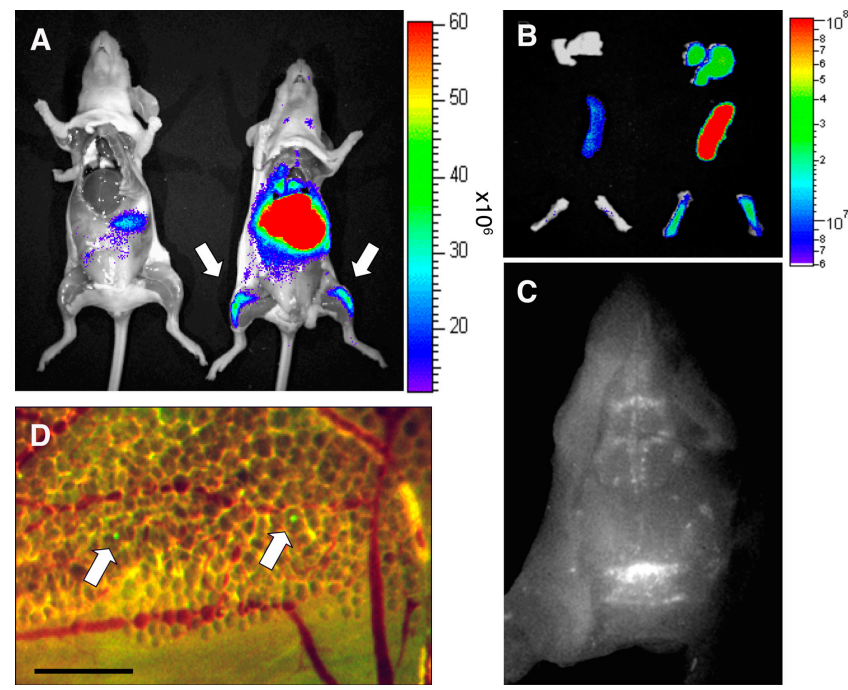

Figure 4. Whole body imaging of $\mathrm{Gr} 1^{\text {high }} \mathrm{BM}$ monocyte recipients. (A) Color-coded near-infrared fluorescent image overlaid on a photographic image of a CD1 nude mouse $16 \mathrm{~h}$ after tail vein injection of DiR-labeled BM monocytes ( $3 \times 10^{6}$ cells; purity: $94 \%$; right). Control (acquired on IVIS 100) is shown on the left. Note the presence of label in femura. (B) Color-coded near-infrared fluorescent image overlaid on a photographic image of isolated lung, spleen, and femura of CD1 nude recipients of DiR-labeled BM monocytes (right) and noninjected control (left; $3 \times 10^{6}$ cells; purity: $94 \%$ ). (C) Monochrome fluorescent microscopy image of a cranium of a CD1 nude mouse that received DiR-labeled BM monocytes $\left(3 \times 10^{6}\right.$ cells; purity: $\left.94 \%\right)$. Note the presence of labeled cells in bone cavities. (D) Dual-channel fluorescent microscopic image of a cranium of a C57BL/6 WT recipient mouse that had received an i.v. injection of CFSE-labeled BM monocytes $\left(3 \times 10^{6}\right.$ cells; purity: 96\%). Arrows indicate two graft-derived cells that extravasated into the $\mathrm{BM}$ parenchyma. Bar, $100 \mu \mathrm{m}$. The data are representative of two independent experiments.

steady-state route $(\mathrm{BM})$ to the peritoneal cavity (Fig. $3 \mathrm{D})$. This indicates further that $\mathrm{Gr} 1^{\text {high }} \mathrm{BM}$ and blood monocyte subsets have functional similarities.

\section{MDPs, but not monocytes, can replenish splenic DCs}

Upon i.v. transfer into irradiated and young nonirradiated recipient mice, MDPs give rise to splenic DCs (10), which are characterized by a frequent steady-state turnover (8). However, MDP differentiation into long-lived MPs, particularly of peripheral tissues, could have been hampered by the limited precursor input in the time window analyzed (10). We therefore sought to improve the engraftment of the MP compartments by depleting DCs and $M \Phi$ s from the recipients before MDP transfer. To this end, we took advantage of CD11c-diphtheria toxin (DTx) receptor (DTR) transgenic mice, which harbor CD11c-expressing MPs, including $M \Phi_{\mathrm{s}}$ and DCs that are sensitive to DTx and are hence depleted upon DTx treatment (24-27). In this conditional cell ablation system, targeted cells die by apoptosis and are removed without causing major inflammation (28). Their replenishment might therefore mimic steady-state conditions. BM chimeras
A
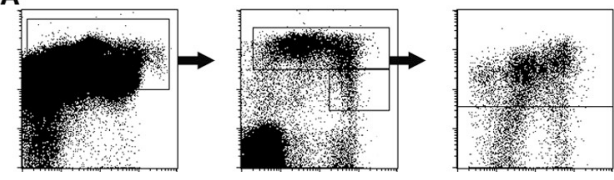

$\mathrm{CX}_{3} \mathrm{CR}^{\mathrm{gtp} /+}$ donor
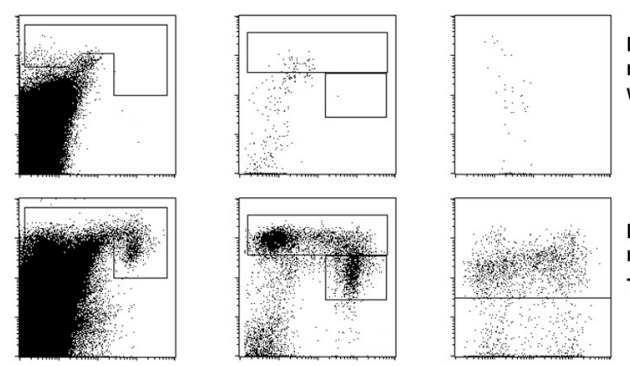

MP-depleted

recipient

w/o graft
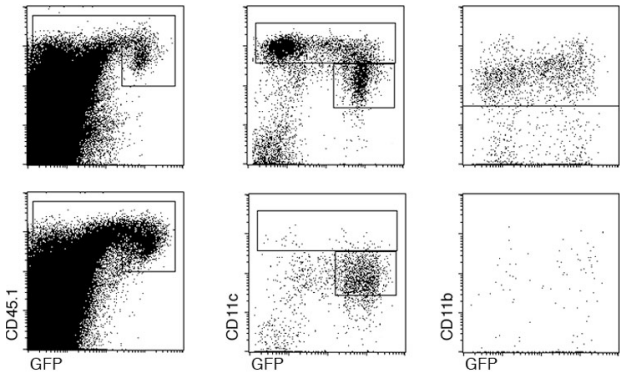

MP-depleted

recipient

+ MDP graft

B MP depleted mouse
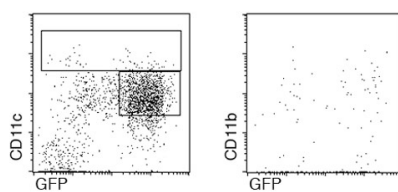

MP-depleted

recipient

+ monocyte graft
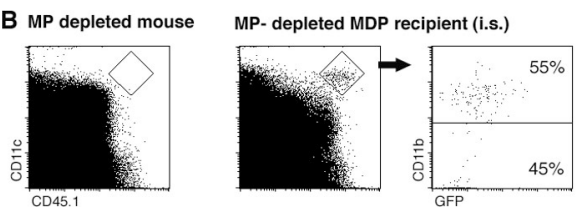

Figure 5. MDPs, but not monocytes, act as precursors of splenic DCs. (A) Flow cytometry analysis of $\mathrm{CX}_{3} \mathrm{CR} 1^{\text {gfp }}$ donor spleen and spleens of DTx-treated, MP-depleted mice with and without engraftment of $\mathrm{CX}_{3}$ CR 1 gfp MDP $\left(8 \times 10^{4} \mathrm{CKit}^{+} \mathrm{CD} 115^{+} \mathrm{Gr}^{-}{ }^{-} \mathrm{CD} 11 \mathrm{~b}^{-}\right.$cells; purity: $\left.80 \%\right)$ and Gr1 ${ }^{\text {high }}$ BM monocytes $\left(8 \times 10^{5} \mathrm{CD} 115^{+} \mathrm{Gr} 1^{+} \mathrm{CD} 11 \mathrm{~b}^{+}\right.$cells; purity: $\left.88 \%\right)$. Note the presence of graft-derived $\left(C D 45.1^{+}\right)$DCs (CD11 $\left.c^{\text {high }}\right)$ in MDP recipients that, as in donor mice $\mathrm{CD}_{11 b^{-}} \mathrm{DC}$, are split into $\mathrm{CX}_{3} \mathrm{CR} 1 / \mathrm{GFP}^{+}$ and $\mathrm{CX}_{3} \mathrm{CR} 1 / \mathrm{GFP}^{-}$cells. CD11 $\mathrm{c}^{\text {high }} / \mathrm{CD} 11 \mathrm{c}^{\text {int }}$ ratios in an MDP recipient: 2.7 in $\mathrm{Gr} 1^{\text {high }}$ monocyte recipient 0.05 (as determined by the indicated gates). (B) Flow cytometry analysis of the spleen of an MP-depleted mouse with and without intra-splenic injection of $\mathrm{CX}_{3} \mathrm{CR} 1^{1 \text { fp }} \mathrm{BM}$ MDPs $\left(2.5 \times 10^{4}\right.$ cells; purity: 96\%). Note the presence of graft-derived (CD45.1 ${ }^{+}$) DCs (CD11 $c^{\text {high }}$ in MDP recipients. The data are representative of two independent experiments.

generated by reconstitution of lethally irradiated WT mice with CD11c-DTR transgenic BM allow for extended MP depletion $(29,30)$. MDPs were isolated from $\mathrm{CX}_{3} \mathrm{CR} 1$ gfp donor mice (CD45.1) and injected into DTx-treated BM chimeras. Analysis of the recipient $7 \mathrm{~d}$ after i.v. MDP transfer revealed the presence of graft-derived $\mathrm{Gr} 1^{\text {high }}$ and $\mathrm{Gr} 1^{\text {low }}$ monocytes in the BM and blood (not depicted). At the same time, the spleen of the MDP recipient mouse was efficiently seeded by DTx-resistant CD11 chigh DCs, including CD11b ${ }^{+}$ and $\mathrm{CD}_{11 \mathrm{~b}^{-}}$cells (Fig. 5 A). As in $\mathrm{CX}_{3} \mathrm{CR} 1^{\text {gfp }}$ donor mice $(10,18)$, CD11 $\mathrm{c}^{+} \mathrm{CD}_{11 b^{-}}\left(\mathrm{CD} 8 \alpha^{+}\right)$DCs could be subdivided into $\mathrm{CX}_{3} \mathrm{CR} 1 / \mathrm{GFP}^{+}$and $\mathrm{CX}_{3} \mathrm{CR} 1 / \mathrm{GFP}^{-}$subsets. In addition, recipient spleens contained an appreciable population of $\mathrm{CD} 11 \mathrm{~b}^{+} \mathrm{CD} 11 \mathrm{c}^{\text {int }}$ cells of unknown identity that were also identified in donor spleens. Because MDPs are in vivo precursors of $\mathrm{Gr} 1^{\text {high }} \mathrm{BM}$ monocytes (Fig. $1 \mathrm{C}$ ), we next investigated the potential of the monocytes to give rise to 
splenic DCs in the MP-depleted recipients. Interestingly, grafted $\mathrm{Gr} 1^{\text {high }} \mathrm{BM}$ monocytes failed to give rise to CD11 $\mathrm{c}^{\text {high }}$ splenic DCs but differentiated almost exclusively into the $\mathrm{CD}_{11 \mathrm{~b}^{+}} \mathrm{CD} 11 \mathrm{c}^{\text {int }}$ population we had previously observed with the MDP graft (Fig. 5 A). Because MDPs are monocyte precursors but the latter do not generate splenic CD11 $c^{\text {high }}$ DCs, we next examined whether MDPs could give rise to splenic DCs without prior differentiation into monocytes, i.e., when placed directly in the spleen. As seen in Fig. 5 B, intra-splenic injection of BM MDPs into MP-depleted mice
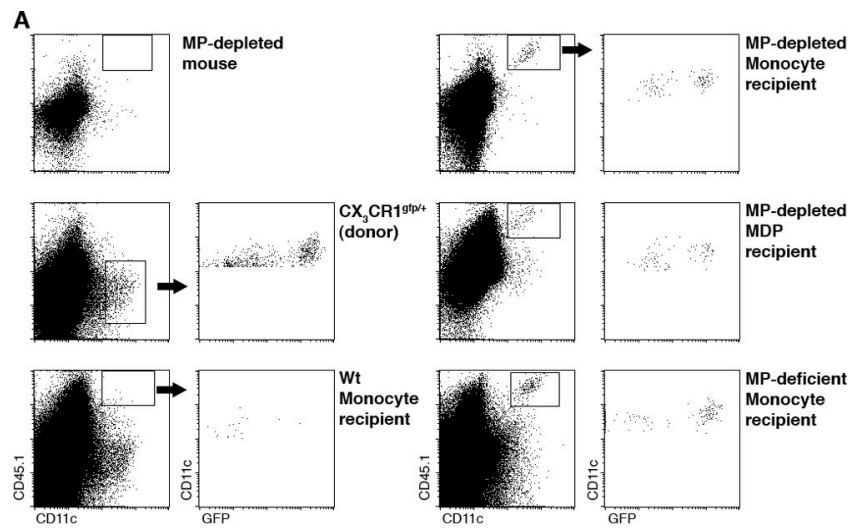

B
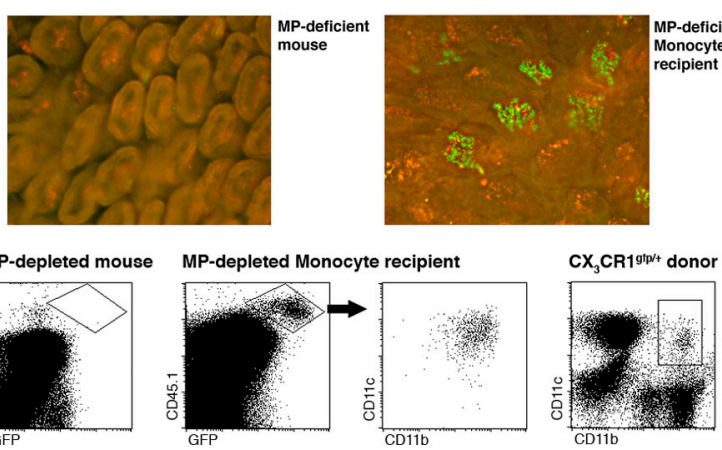

Figure 6. Monocytes are precursors of MPs in the intestine and lung. (A) Flow cytometry analysis of small intestinal lp cells isolated from a $\mathrm{CX}_{3} \mathrm{CR} 1^{\text {gfp }}$ donor mouse, as well as of WT, MP-depleted, and MP-deficient recipients of $\mathrm{CX}_{3} \mathrm{CR} 1{ }^{\text {gfp }} \mathrm{Gr}$ 1 $^{\text {high }} \mathrm{BM}$ monocytes and MDPs (7 d after i.v. transfer of $8 \times 10^{5} \mathrm{CD} 115^{+} \mathrm{CD} 11 \mathrm{~b}^{+} \mathrm{Gr} 1^{+}$monocytes [purity: $88 \%$ ] or $8 \times 10^{4} \mathrm{CD}_{117}+\mathrm{Gr} 1^{-} \mathrm{CD} 11 b^{-} \mathrm{MDPs}$ [purity: 80\%]). Note the presence of graft-derived $\left(C D 45.1^{+}\right) \mathrm{CD}_{11 \mathrm{c}^{+}} \mathrm{CX}_{3} \mathrm{CR} 1 / \mathrm{GFP}^{+}$IpDCs and $\mathrm{CD} 11 \mathrm{c}^{+} \mathrm{CX}_{3} \mathrm{CR} 1 /$ GFP- IpMФs in donors and MP-depleted and MP-deficient recipients of precursor grafts. The data are representative of three independent experiments. (B) Fluorescence microscopy analysis of small intestinal villi of mice constitutively lacking IpDCs and IpM $\Phi$ s with or without adoptive transfer of $\mathrm{CX}_{3} \mathrm{CR} 1 \mathrm{~g}^{\text {fp }} \mathrm{BM}$ monocytes $\left(10^{6} \mathrm{CD} 115^{+} \mathrm{Gr} 1^{\text {high }} \mathrm{CD} 11 \mathrm{~b}^{+}\right.$cells; purity: $85 \%$ ). Note the presence of graft-derived $\mathrm{CX}_{3} \mathrm{CR} 1 / \mathrm{GFP}^{+} \mathrm{IpDCs}$ in the live tissue of a BM monocyte recipient. Bar, $100 \mu \mathrm{m}$. The data are representative of three independent experiments. (C) Flow cytometry analysis of parenchymal lung cells isolated from $\mathrm{CX}_{3} \mathrm{CR} 1^{\text {ffp }}$ donor mouse, an MP-depleted mouse, and MP-depleted recipients of $\mathrm{CX}_{3} \mathrm{CR} 19^{\mathrm{fp}} \mathrm{Gr} 1^{\text {high }}$ BM monocytes (7 d after i.v. transfer of $7.5 \times 10^{5} \mathrm{CD} 115^{+} \mathrm{Gr} 1^{+} \mathrm{CD}_{11} \mathrm{~b}^{+}$ cells; purity: $85 \%)$. Note the presence of graft-derived (CD45.1 $1^{+}$) CD11 ${ }^{+}$ $\mathrm{CD}_{11} \mathrm{~b}^{+} \mathrm{CX}_{3} \mathrm{CR} 1 / \mathrm{GFP}+$ lung DCs in the graft recipient. The data are representative of two independent experiments. yielded $\mathrm{CD}_{11} \mathrm{~b}^{+}$and CD11 $\mathrm{b}^{-} \mathrm{CD} 11 \mathrm{c}^{\text {high }} \mathrm{DCs}$. This suggests that local spleen-resident precursors, such as MDPs, might replenish the CD11 $c^{\text {high }}$ DC population without a monocytic intermediate.

\section{Monocytes replenish intestinal Ip and lung DCs}

Because monocytes are established DC precursors (3), we decided to investigate whether the grafted Gr1 ${ }^{\text {high }} \mathrm{BM}$ monocytes can give rise to DCs in other nonlymphoid tissues. We first chose to study the seeding of the intestinal lp, which, as we recently reported, contains two discrete populations of $\mathrm{CX}_{3} \mathrm{CR} 1^{+}$lpDCs and $\mathrm{CX}_{3} \mathrm{CR} 1^{-} \operatorname{lpM} \Phi \mathrm{s}(27,31)$. Both of these cell types are CD11 ${ }^{+}$and hence DTx sensitive in CD11c-DTR transgenic mice and [DTR $\rightarrow$ WT] mixed BM chimeras $(27,29)$. When transferred into untreated WT mice, Gr1 $1^{\text {high }} \mathrm{BM}$ monocytes essentially failed to give rise to lpMP, as indicated by the absence of CD 11c ${ }^{+}$CD $45.1^{+}$cells (Fig. 6 A). DTx-induced lpMP depletion in the [DTR $\rightarrow$ WT] recipients, however, promoted the efficient seeding of this peripheral tissue with graft-derived (CD45.1+) $\mathrm{CX}_{3} \mathrm{CR} 1 /$ $\mathrm{GFP}^{+}$lpDCs and $\mathrm{CX}_{3} \mathrm{CR} 1 / \mathrm{GFP}^{-}$lpM $\Phi_{\mathrm{s}}$ (Fig. 6 A). lpMPs were also observed after the adoptive transfer of MDPs (Fig. 6 A). To address the potential role of inflammatory signals associated with our conditional ablation strategy in graft recruitment and differentiation, we repeated the experiment using a novel strain of mice that constitutively lacks CD $11 \mathrm{c}^{+} 1 \mathrm{pMPs}$ and was recently developed in our laboratory (to be described elsewhere). Flow cytometry and histological analysis of these recipient mice showed efficient engraftment of their lp with CD45.1 ${ }^{+} \mathrm{CX}_{3} \mathrm{CR} 1 / \mathrm{GFP}^{+} \mathrm{lpDCs}$ and $\mathrm{CX}_{3} \mathrm{CR} 1 / \mathrm{GFP}^{-}$lpM $\Phi_{\mathrm{s}}$ (Fig. 6, A and B), arguing in favor of the homeostatic nature of this MP differentiation route. However, further experimentation will be needed to assess the contribution of the $M \Phi / D C$ depletion to the process. Notably, recruitment could also be mediated by constitutively expressed inflammatory signals present at the mucosal tissues. Further clarification of this issue will require the definition of the molecular parameters that guide the transferred cells to the $1 \mathrm{p}$. To extend our analysis to another nonlymphoid organ, we studied the lung parenchyma of CD11c-DTR transgenic recipient mice that were depleted of lung DCs by intra-tracheal DTx instillation (26). Grafted Gr1 ${ }^{\text {high }}$ BM monocytes gave efficient rise to lung DCs, which can be defined by coexpression of the CD11c and CD11b integrins, as well as of $\mathrm{CX}_{3} \mathrm{CR} 1$ (32, 33, 56; Fig. $\left.6 \mathrm{C}\right)$.

Collectively, adoptively transferred monocytes fail to give rise to CD $11 c^{\text {high }}$ DCs in the spleen but efficiently do so in the intestinal $\mathrm{lp}$ and lung. These results suggest a differential contribution of monocytes and MDPs to the lymphoid and nonlymphoid DC compartment.

\section{DISCUSSION}

Here, we report three novel findings on the origin, interrelation, and fate of murine MPs. First, we establish that a recently reported MDP (10) differentiates in vivo into BM and blood monocytes. Second, we show that in the absence of 
inflammation, the previously reported Gr $1^{\text {high }}$ inflammatory monocyte subset (15) homes back to the BM, recycles, and takes further part in MP differentiation. Third, and most importantly, our data together with other recent studies (10, 34-36) establish that the spleen relies on a distinct nonmonocytic DC precursor input. In contrast, nonlymphoid tissues including the intestinal $\mathrm{lp}$, lung, and epidermis-possibly most peripheral tissues-are seeded by monocytes for renewal of DCs. At least in some cases, however, the role of monocytes in reseeding tissue DCs is subordinate to local self-renewal (7).

Maintenance of most peripheral MPs is believed to require continuous replenishment from the BM. This includes the short-lived DC compartment (37), but also МФs. However, the latter (38-40) and, more recently, splenic DCs (34, 41) were also reported to be capable of limited self-renewal. The link between the BM and peripheral $M \Phi_{\mathrm{S}}$ or DCs is thought to be provided by circulating blood monocytes (Fig. S1, available at http://www.jem.org/cgi/content/full/ jem.20061011/DC1). Despite this critical position in the MP differentiation pathway, the in vivo biology of this ephemeral MP intermediate $(13,15,16,35,42,43)$ remains poorly understood. Based on the expression of the chemokine receptors $\mathrm{CX}_{3} \mathrm{CR} 1$ and CCR2, human and murine peripheral blood monocytes can be subdivided into two major populations (11). Furthermore, studies in the mouse suggested that these subsets are functionally distinguishable in that inflammatory $\mathrm{CX}_{3} \mathrm{CR} 1^{\text {low }} \mathrm{CCR} 2^{+} \mathrm{Gr} 1(\mathrm{Ly} 6 \mathrm{C} / \mathrm{G})^{\text {high }}$ monocytes are preferentially recruited to sites of tissue damage, whereas $\mathrm{CX}_{3} \mathrm{CR} 1^{\text {high }} \mathrm{Gr} 1(\mathrm{Ly} 6 \mathrm{C} / \mathrm{G})^{\text {low }}$ cells extravasate spontaneously to resting tissues (15). Beyond this dichotomy, "monocytes" are likely to include additional minor subpopulations, as suggested by the recent identification of the $\mathrm{Ly} 6 \mathrm{C}^{\text {mid }} \mathrm{CCR} 7^{+}$ CCR $8^{+}$subset $(16,20)$, as well as subsets with novel proangiogeneic activities $(44,45)$.

Monocytes are known to originate in the $\mathrm{BM}$ from a granulocyte-myeloid precursor (9). More recently, we identified a BM-resident clonotypic MP progenitor that, as opposed to a granulocyte-myeloid precursor, lost the potential to differentiate into granulocytes. Instead, when cultured under the appropriate in vitro conditions or transferred into recipient mice, the $\mathrm{CX}_{3} \mathrm{CR} 1^{+} \mathrm{CD} 117^{+}$lin $^{-}$cells expanded and gave rise exclusively to $M \Phi$ s and DCs. They were hence named MDPs for M $\Phi / D C$ precursors (10). We now investigated the potential of MDPs to differentiate within their native BM microenvironment. Using IBC transfer, we showed that the $\mathrm{CD}_{11} \mathrm{~b}^{-} \mathrm{Gr} 1(\mathrm{Ly} 6 \mathrm{C} / \mathrm{G})^{-}$MDPs differentiate into $\mathrm{CD}_{11 b^{+}}$Gr1(Ly6C/G) ${ }^{\text {high }}$ and $\mathrm{CD} 11 \mathrm{~b}^{+} \mathrm{Gr} 1(\mathrm{Ly} 6 \mathrm{C} / \mathrm{G})^{\text {low }}$ $\mathrm{BM}$ monocytes, which have been previously reported and are potentially able to differentiate into MPs $(46,47)$. The IBC transfer also allowed the detection of graft-derived peripheral blood monocytes. These data, together with the results obtained from subsequent IBC transfers of the $\mathrm{Gr} 1^{\text {high }} \mathrm{BM}$ monocyte intermediate, document a sequence of myeloid differentiation from a BM-resident precursor via BM-resident intermediates to circulating blood monocytes (Fig. S1).
In most current schemes of myeloid differentiation, the blood monocyte appears as a "one-way intermediate" from the BM to the periphery (11). A most intriguing finding of our studies is, however, that blood monocytes efficiently home back to the BM (Fig. S1). Thus, after IBC transfer of MDPs, we unexpectedly retrieved graft-derived cells from the noninjected contra-lateral bone. Using IBC and i.v. engraftment of $\mathrm{Gr} 1^{\text {high }} \mathrm{BM}$ monocytes, we directly showed that this cell population is responsible for the inter-BM translocation. The i.v. transfer of blood monocytes further revealed that the BM homing potential is inherent to all $\mathrm{Gr} 1^{\text {high }}$ monocytes. We previously reported that $\mathrm{Gr} 1^{\text {high }}$ blood monocytes are dedicated to migrate to sites of inflammation but in the absence of the latter disappeared from the circulation of recipient mice (15). Our present results strongly suggest that the grafted $\mathrm{Gr} 1^{\text {high }}$ inflammatory monocytes in these studies had shuttled back to the BM. Furthermore, they might also provide an explanation for the reported loss of grafted monocytes in other studies (16). Importantly, Gr1 $1^{\text {high }} \mathrm{BM}$ and blood monocytes that returned to the BM converted into Gr1 $1^{\text {low }}$ monocytes and contributed further to MP generation (see below). Peripheral blood monocyte shuttling to the BM likely plays a role in antigen acquisition (43). Furthermore, it will have to be taken in consideration when interpreting the results of parabiosis experiments. Murine blood monocytes ingest Listeria monocytogenes upon in vivo challenge and critically contribute to dissemination of the bacteria to the brain (48). Moreover, circulating phagocytes have been implied in the systemic spreading of Salmonella typhimurium after oral challenge (49). Blood monocyte shuttling to the BM could be exploited by pathogens to reach this immuno-privileged compartment and establish persistent infection or latency.

Sunderkotter et al. (16) reported that Ly6C high $^{\text {hood }}$ monocytes differentiate into Ly6C $\mathrm{C}^{\text {low }}$ monocytes. Together with the identification of a $\mathrm{Ly} 6 \mathrm{C}^{\text {mid }} \mathrm{CCR} 7{ }^{+} \mathrm{CCR} 8^{+}$monocyte subset in the blood, this led to the suggestion that monocyte conversion occurs within the circulation $(16,20)$. Our Gr1 $(\mathrm{Ly} 6 \mathrm{C} / \mathrm{G})^{\text {high }} \mathrm{BM}$ and blood monocyte transfer studies provide further direct evidence that this monocyte subset acts as an efficient precursor pool of Gr1 $1^{\text {low }} \mathrm{BM}$ and blood monocytes. However, given the kinetics of the BM monocyte subset appearance after IBC transfer and the efficient BM homing of the i.v injected Gr $1^{\text {high }}$ monocytes, our results suggest that the BM is a major site of monocyte conversion. This could also explain the reported transient loss of fluorochromelabeled Ly6 $\mathrm{C}^{\text {high }}$ blood monocytes and their reappearance as Ly6C ${ }^{\text {low }}$ cells (16).

We recently noted that adoptively transferred monocytes fail to differentiate into splenic DCs (10). We have now substantiated this observation by using the conditional depletion of splenic host DCs, thereby boosting replenishment of the DC compartment by grafted cells. Strikingly, adoptively transferred monocytes efficiently seeded the recipient spleen with CD11 $\mathrm{c}^{\mathrm{int}}$ progenies but did not give rise to splenic CD$11 \mathrm{c}^{\text {high }}$ DCs. In contrast, in the same MP-depleted mice, the grafted Gr1 ${ }^{\text {high }}$ monocytes efficiently reconstituted the small 
intestinal $\mathrm{lp}$ with $\mathrm{lpDCs}$ and $\mathrm{lpM} \Phi \mathrm{s}$ (27). Furthermore, grafted Gr1 $1^{\text {high }}$ monocytes also gave rise to DCs in another nonlymphoid tissue, the lung. Importantly, the conversion of Gr1 $1^{\text {high }}$ monocytes into $\mathrm{Gr} 1^{\text {low }}$ cells precludes drawing the conclusion that the Gr1 $1^{\text {high }}$ monocyte subset is the direct precursor of the intestinal and lung DCs in the present study. Notably, Yrlid et al. (17) recently reported that in the rat, the CCR $2^{\text {neg }}$ monocyte subset has the potential to differentiate into intestinal lymph DCs (17), and we observed the generation of lung DCs from adoptively transferred fractionated Gr1 $1^{\text {low }}$ blood monocytes (unpublished data).

Recent studies indicate that steady-state DC maintenance in lymphoid organs might be independent of monocyte input, and that spleen DCs have the potential for self-renewal or rely on local precursors $(34,41)$. The i.v. and intra-splenic transfer of MDPs shows that BM MDPs can give rise to splenic CD11 $\mathrm{c}^{\text {high }} \mathrm{DCs}$, including both CD $11 \mathrm{~b}^{+}$and CD11 $\mathrm{b}^{-}$ cells. These findings suggest that spleen-resident precursors might give rise to steady-state DCs in the spleen without a monocytic intermediate. Interestingly, such a cell with DC differentiation potential has recently been reported by Naik et al. (36), and it will be important to establish the link of these so-called "pre-cDCs" to the MDP.

The heterogeneity of the body-wide M $\Phi / \mathrm{DC}$ network and the emerging differential in vivo functions of distinct $\mathrm{M} \Phi / \mathrm{DC}$ subsets $(24,50)$ suggest that manipulation of the MP system might be of therapeutic value. Rather than transferring terminally differentiated MPs, which cannot faithfully be generated in vitro and are unlikely to reach the desired physiological microenvironment, MP system manipulation could rely on precursor differentiation in their physiological context. Such strategies will, however, require an in-depth understanding of the underlying MP differentiation pathways. In our study, we have established two sequences of in vivo MP differentiation using recipient mice in which we conditionally ablated defined MPs in lymphoid and nonlymphoid organs. We show that adoptively transferred MDPs (10) can reconstitute DCs in the spleen and intestinal lp, whereas engraftment with monocytes allows efficient seeding of nonlymphoid tissues with $M \Phi_{s}$ and DCs. Importantly, grafted Gr1 $(\mathrm{Ly} 6 \mathrm{C} / \mathrm{G})^{\text {high }}$ monocytes efficiently home to the BM and enter physiological differentiation pathways. Combined with the recent progress in our understanding of the molecular checkpoints of MP precursor differentiation (51-54), genetically modified precursor grafts might allow the development of strategies for the manipulation of the peripheral MP pool.

\section{MATERIALS AND METHODS}

Animals. This study involved the use of WT, heterozygote mutant $\mathrm{CX}_{3} \mathrm{CR} 1^{+/ g p p}(18)$, and CD11c-DTR transgenic mice (B6.FVB-Tg [ItgaxDTR/GFP] 57Lan/J; reference 24), all of which were backcrossed against a C57BL/ 6 background. All whole body imaging was performed on CD1 nude recipients. Recipient mice that constitutively lack CD11 $\mathrm{c}^{\text {high }} \mathrm{MPs}$ will be described elsewhere. Mixed [DTR $\rightarrow$ WT] BM chimeras for conditional MP ablation were generated as reported previously (29). In brief, C57BL/6 WT mice were exposed to a single lethal dose of 950 rad total body irradiation, followed by i.v. transfer of $5 \times 10^{6} \mathrm{CD} 11 \mathrm{c}-\mathrm{DTR}$ transgenic BM cells. The mice were allowed to rest for 8 wk before use. For systemic MP depletion, DTR transgenic BM chimeras were inoculated intraperitoneally every other day with DTx (D-2918; Sigma-Aldrich) at $8 \mathrm{ng} / \mathrm{g}$ body weight (29). For pulmonary MP depletion, we intratracheally installed 100 ng DTx (26 and unpublished data). Peritoneal sterile inflammation was induced by injection of thioglycollate (Diffco). All mice were maintained under specific pathogenfree conditions and handled according to protocols approved by the Weizmann Institute Animal Care Committee as per international guidelines.

Isolation of MDP and BM monocyte precursor grafts. BM cells were harvested from the femora and tibiae of $\mathrm{CX}_{3} \mathrm{CR} 1^{\mathrm{GFP} /+} \mathrm{CD} 45.1$ mice and enriched for mononuclear cells on a Ficoll density gradient. The cells were then immunostained with anti-CD117-PE, anti-CD11b-PECy7/PerCP, and anti-Gr1-APC fluorochrome-conjugated antibodies. MDP cells were identified as $\mathrm{CX}_{3} \mathrm{CR} 1$ (GFP), CD117 (cKit) positive cells negative for CD11b and Gr1 markers. These cells were purified by high speed sorting using a FACS Aria (Becton Dickinson) and injected i.v. into congenic CD45.2 WT mice or DTx-treated mixed [DTR $\rightarrow$ WT] BM chimeras. Gr1 $1^{\text {high }} \mathrm{BM}$ monocytes were isolated by high speed sorting of the Gr1 ${ }^{\text {high }} \mathrm{CD} 11 \mathrm{~b}^{+} \mathrm{CD} 115^{+} \mathrm{BM}$ cell fraction. For IVIS and intravital microscopy experiments, the monocyte graft was isolated through MACS enrichment using biotinylated anti-CD115 antibodies and streptavidin-coupled magnetic beads (Miltenyi Biotec).

Adoptive transfer procedure. If not indicated otherwise, $0.2 \mathrm{ml}$ PBS containing the respective cell populations was injected into the tail vein. For spleen and IBC transfer, mice were anesthetized with a mixture containing $15 \%$ xylazin $(20 \mathrm{mg} / \mathrm{ml}$; Vitamed) and $85 \%$ ketaset $(100 \mathrm{mg} / \mathrm{ml}$; Fort Dodge Animal Health). Cells were injected directly into the spleen $(20 \mu \mathrm{l} \mathrm{vol})$ or into the BM cavity ( $\sim 5 \mu \mathrm{lol}$ ) using a $\mathrm{U}-100$ insulin syringe (with a $30-\mathrm{G}$ needle; Becton Dickinson). For IBC transfer, the knee side of the femur was pierced in advance with a $27-\mathrm{G} 1 / 2$ needle.

Analysis of recipient mice and flow cytometry. lp cells were isolated as described previously (27). Fluorochrome-labeled monoclonal antibodies were purchased from BD Biosciences or eBioscience and used according to the manufacturer's instructions. Cells were analyzed with a FACSCalibur cytometer (Becton Dickinson) using CELLQuest software (Becton Dickinson).

Whole body and fluorescent imaging. Isolated monocytes were labeled ex vivo with the near infrared lipophilic carbocyanine dye 1,1'-dioctadecyl$3,3,3^{\prime}, 3^{\prime}$-tetramethylindotricarbocyanine iodide (DiR; Invitrogen) for $1 \mathrm{~h}$ (21). Labeled cells were injected i.v. into CD1 nude mice. DiR-labeled monocyte localization within the intact animal, as well as isolated within organs, was assessed using the IVIS 100 Series Imaging System (Xenogen). The excitation (Ex) and emission (Em) filter sets were 710-760 and 810-760 nm, respectively. For intravital microscopy imaging, monocytes were labeled with the intracellular fluorescent dye, CFSE (Invitrogen). Monocytes in the cranium were visualized using a Zoom Stereo Microscope SZX-RFL-2 (Olympus) equipped with a fluorescence illuminator and a CCD camera Pixelfly QE (PCO). The Ex and Em filter for fluorescence in the visual spectrum were: Ex 460-490/ Em 510-550 nm (green channel) and Ex 520$550 \mathrm{~nm} /$ Em 580-630 nm (red channel). The Ex 710-750/Em 780-830 nm filter set was used for fluorescence in the near-infrared spectrum. Images were acquired using camera-controlling software (Camware; PCO) with Image 1.330 software.

Online supplemental material. Fig. S1 shows a scheme summarizing our current understanding of the origins and context-dependent fate of murine monocyte subsets. It is available at http://www.jem.org/cgi/content/ full/jem.20061011/DC1.

We thank Drs. R. Alon, Y. Pewzner-Jung, and A. Mahler for critical reading of the manuscript; R. Krauthgamer, E. Ariel, and A. Sharp for help with flow cytometry; and $Y$. Chermesh and 0 . Amram for animal husbandry. 
This work was supported by the MINERVA Foundation, the Israel Science Foundation, and the EU6 Program for Migration and Inflammation Network. S. Jung is the incumbent of the Pauline Recanati Career Development Chair and a Scholar of the Benoziyo Center for Molecular Medicine. F. Geissmann is supported by INSERM, the City of Paris, the FRM, the Fondation de France, and the Fondation Schlumberger.

The authors have no conflicting financial interests.

Submitted: 10 May 2006

Accepted: 22 November 2006

\section{REFERENCES}

1. Metchnikoff, E. 1887. Ueber den Kampf der Zellen gegen Erypselkokken, ein Beitrag zur Phagocytenlehre. Arch. Pathol. Anat. (Virchow's Archive) 107:209-249.

2. Steinman, R.M., and Z.A. Cohn. 1973. Identification of a novel cell type in peripheral lymphoid organs of mice. I. Morphology, quantitation, tissue distribution. J. Exp. Med. 137:1142-1162.

3. Taylor, P.R., L. Martinez-Pomares, M. Stacey, H.H. Lin, G.D. Brown, and S. Gordon. 2005. Macrophage receptors and immune recognition. Annu. Rev. Immunol. 23:901-944.

4. Shortman, K., and Y.J. Liu. 2002. Mouse and human dendritic cell subtypes. Nat. Rev. Immunol. 2:151-161.

5. Godin, I., and A. Cumano. 2002. The hare and the tortoise: an embryonic haematopoietic race. Nat. Rev. Immunol. 2:593-604.

6. Hickey, W.F., K. Vass, and H. Lassmann. 1992. Bone marrow-derived elements in the central nervous system: an immunohistochemical and ultrastructural survey of rat chimeras. J. Neuropathol. Exp. Neurol. 51:246-256.

7. Merad, M., M.G. Manz, H. Karsunky, A. Wagers, W. Peters, I. Charo, I.L. Weissman, J.G. Cyster, and E.G. Engleman. 2002. Langerhans cells renew in the skin throughout life under steady-state conditions. Nat. Immunol. 3:1135-1141.

8. Kamath, A.T., S. Henri, F. Battye, D.F. Tough, and K. Shortman. 2002. Developmental kinetics and lifespan of dendritic cells in mouse lymphoid organs. Blood. 100:1734-1741.

9. Akashi, K., D. Traver, T. Miyamoto, and I.L. Weissman. 2000. A clonogenic common myeloid progenitor that gives rise to all myeloid lineages. Nature. 404:193-197.

10. Fogg, D.K., C. Sibon, C. Miled, S. Jung, P. Aucouturier, D.R. Littman, A. Cumano, and F. Geissmann. 2005. A clonogenic bone marrow progenitor specific for macrophages and dendritic cells. Science. 311:83-87.

11. Gordon, S., and P.R. Taylor. 2005. Monocyte and macrophage heterogeneity. Nat. Rev. Immunol. 5:953-964.

12. Passlick, B., D. Flieger, and H.W. Ziegler-Heitbrock. 1989. Identification and characterization of a novel monocyte subpopulation in human peripheral blood. Blood. 74:2527-2534.

13. Palframan, R.T., S. Jung, G. Cheng, W. Weninger, Y. Luo, M. Dorf, D.R. Littman, B.J. Rollins, H. Zweerink, A. Rot, and U.H. von Andrian. 2001. Inflammatory chemokine transport and presentation in HEV: a remote control mechanism for monocyte recruitment to lymph nodes in inflamed tissues. J. Exp. Med. 194:1361-1373.

14. Maus, U., K. von Grote, W.A. Kuziel, M. Mack, E.J. Miller, J. Cihak, M. Stangassinger, R. Maus, D. Schlondorff, W. Seeger, and J. Lohmeyer. 2002. The role of CC chemokine receptor 2 in alveolar monocyte and neutrophil immigration in intact mice. Am. J. Respir. Crit. Care Med. 166:268-273.

15. Geissmann, F., S. Jung, and D.R. Littman. 2003. Blood monocytes consist of two principal subsets with distinct migratory properties. Immunity. 19:71-82.

16. Sunderkotter, C., T. Nikolic, M.J. Dillon, N. Van Rooijen, M. Stehling, D.A. Drevets, and P.J. Leenen. 2004. Subpopulations of mouse blood monocytes differ in maturation stage and inflammatory response. J. Immunol. 172:4410-4417.

17. Yrlid, U., C.D. Jenkins, and G.G. MacPherson. 2006. Relationships between distinct blood monocyte subsets and migrating intestinal lymph dendritic cells in vivo under steady-state conditions. J. Immunol. 176:4155-4162

18. Jung, S., J. Aliberti, P. Graemmel, M.J. Sunshine, G.W. Kreutzberg, A. Sher, and D.R. Littman. 2000. Analysis of fractalkine receptor
CX(3)CR1 function by targeted deletion and green fluorescent protein reporter gene insertion. Mol. Cell. Biol. 20:4106-4114.

19. de Bruijn, M.F., W.A. Slieker, J.C. van der Loo, J.S. Voerman, W. van Ewijk, and P.J. Leenen. 1994. Distinct mouse bone marrow macrophage precursors identified by differential expression of ER-MP12 and ER-MP20 antigens. Eur. J. Immunol. 24:2279-2284.

20. Qu, C., E.W. Edwards, F. Tacke, V. Angeli, J. Llodra, G. SanchezSchmitz, A. Garin, N.S. Haque, W. Peters, N. van Rooijen, et al. 2004. Role of CCR 8 and other chemokine pathways in the migration of monocyte-derived dendritic cells to lymph nodes. J. Exp. Med. 200:1231-1241

21. Kalchenko, V., S. Shivtiel, V. Malina, K. Lapid, S. Haramati, A. Brill, T. Lapidot, and A. Harmelin. 2006. Use of lipophilic near infrared dye in whole body optical imaging of hematopoietic cell homing. J. Biomed. Opt. 11:050507.

22. Martin, C., P.C. Burdon, G. Bridger, J.C. Gutierrez-Ramos, T.J. Williams, and S.M. Rankin. 2003. Chemokines acting via CXCR 2 and CXCR 4 control the release of neutrophils from the bone marrow and their return following senescence. Immunity. 19:583-593.

23. Henderson, R.B., J.A. Hobbs, M. Mathies, and N. Hogg. 2003. Rapid recruitment of inflammatory monocytes is independent of neutrophil migration. Blood. 102:328-335.

24. Jung, S., D. Unutmaz, P. Wong, G. Sano, K. De los Santos, T. Sparwasser, S. Wu, S. Vuthoori, K. Ko, F. Zavala, et al. 2002. In vivo depletion of $\mathrm{CD} 11 \mathrm{c}(+)$ dendritic cells abrogates priming of CD8(+) T cells by exogenous cell-associated antigens. Immunity. 17:211-220.

25. Probst, H.C., K. Tschannen, B. Odermatt, R. Schwendener, R.M. Zinkernagel, and M. Van Den Broek. 2005. Histological analysis of CD11c-DTR/GFP mice after in vivo depletion of dendritic cells. Clin. Exp. Immunol. 141:398-404.

26. van Rijt, L.S., S. Jung, A. Kleinjan, N. Vos, M. Willart, C. Duez, H.C. Hoogsteden, and B.N. Lambrecht. 2005. In vivo depletion of lung $\mathrm{CD} 11 \mathrm{c}^{+}$dendritic cells during allergen challenge abrogates the characteristic features of asthma. J. Exp. Med. 201:981-991.

27. Vallon-Eberhard, A., L. Landsman, N. Yogev, B. Verrier, and S. Jung. 2006. Transepithelial pathogen uptake into the small intestinal lamina propria. J. Immunol. 176:2465-2469.

28. Bennett, C.L., E. van Rijn, S. Jung, K. Inaba, R.M. Steinman, M.L. Kapsenberg, and B.E. Clausen. 2005. Inducible ablation of mouse Langerhans cells diminishes but fails to abrogate contact hypersensitivity. J. Cell Biol. 169:569-576.

29. Zaft, T., A. Sapoznikov, R. Krauthgamer, D.R. Littman, and S. Jung. 2005. CD11chigh dendritic cell ablation impairs lymphopeniadriven proliferation of naive and memory CD8 $+\mathrm{T}$ cells. J. Immunol. 175:6428-6435

30. Zammit, D.J., L.S. Cauley, Q.M. Pham, and L. Lefrancois. 2005. Dendritic cells maximize the memory CD8 $\mathrm{T}$ cell response to infection. Immunity. 22:561-570.

31. Niess, J.H., S. Brand, X. Gu, L. Landsman, S. Jung, B.A. McCormick, J.M. Vyas, M. Boes, H.L. Ploegh, J.G. Fox, et al. 2005. CX3CR1mediated dendritic cell access to the intestinal lumen and bacterial clearance. Science. 307:254-258.

32. Gonzalez-Juarrero, M., T.S. Shim, A. Kipnis, A.P. Junqueira-Kipnis, and I.M. Orme. 2003. Dynamics of macrophage cell populations during murine pulmonary tuberculosis. J. Immunol. 171:3128-3135.

33. Julia, V., E.M. Hessel, L. Malherbe, N. Glaichenhaus, A. O'Garra, and R.L. Coffman. 2002. A restricted subset of dendritic cells captures airborne antigens and remains able to activate specific $\mathrm{T}$ cells long after antigen exposure. Immunity. 16:271-283.

34. Kabashima, K., T.A. Banks, K.M. Ansel, T.T. Lu, C.F. Ware, and J.G. Cyster. 2005. Intrinsic lymphotoxin-beta receptor requirement for homeostasis of lymphoid tissue dendritic cells. Immunity. 22:439-450.

35. Ginhoux, F., F. Tacke, V. Angeli, M. Bogunovic, M. Loubeau, X.M Dai, E.R. Stanley, G.J. Randolph, and M. Merad. 2006. Langerhans cells arise from monocytes in vivo. Nat. Immunol. 7:265-273.

36. Naik, S.H., D. Metcalf, A. van Nieuwenhuijze, I. Wicks, L. Wu, M. O'Keeffe, and K. Shortman. 2006. Intrasplenic steady-state dendritic cell precursors that are distinct from monocytes. Nat. Immunol. 7 : $663-671$. 
37. Kamath, A.T., J. Pooley, M.A. O’Keeffe, D. Vremec, Y. Zhan, A.M. Lew, A. D'Amico, L. Wu, D.F. Tough, and K. Shortman. 2000. The development, maturation, and turnover rate of mouse spleen dendritic cell populations. J. Immunol. 165:6762-6770.

38. Tarling, J.D., H.S. Lin, and S. Hsu. 1987. Self-renewal of pulmonary alveolar macrophages: evidence from radiation chimera studies. J. Leukoc. Biol. 42:443-446.

39. van Furth, R., and M.M. Diesselhoff-den Dulk. 1984. Dual origin of mouse spleen macrophages. J. Exp. Med. 160:1273-1283.

40. Mebius, R.E., G. Martens, J. Breve, F.G. Delemarre, and G. Kraal. 1991 Is early repopulation of macrophage-depleted lymph node independent of blood monocyte immigration? Eur. J. Immunol. 21:3041-3044.

41. Zhang, M., H. Tang, Z. Guo, H. An, X. Zhu, W. Song, J. Guo, X. Huang, T. Chen, J. Wang, and X. Cao. 2004. Splenic stroma drives mature dendritic cells to differentiate into regulatory dendritic cells. Nat. Immunol. 5:1124-1133.

42. Randolph, G.J., K. Inaba, D.F. Robbiani, R.M. Steinman, and W.A. Muller. 1999. Differentiation of phagocytic monocytes into lymph node dendritic cells in vivo. Immunity. 11:753-761.

43. Tacke, F., F. Ginhoux, C. Jakubzick, N. van Rooijen, M. Merad, and G.J. Randolph. 2006. Immature monocytes acquire antigens from other cells in the bone marrow and present them to $\mathrm{T}$ cells after maturing in the periphery. J. Exp. Med. 203:583-597.

44. De Palma, M., M.A. Venneri, R. Galli, L.S. Sergi, L.S. Politi, M. Sampaolesi, and L. Naldini. 2005. Tie2 identifies a hematopoietic lineage of proangiogenic monocytes required for tumor vessel formation and a mesenchymal population of pericyte progenitors. Cancer Cell. $8: 211-226$.

45. Grunewald, M., I. Avraham, Y. Dor, E. Bachar-Lustig, A. Itin, S. Yung, S. Chimenti, L. Landsman, R. Abramovitch, and E. Keshet. 2006. VEGF-induced adult neovascularization: recruitment, retention, and role of accessory cells. Cell. 124:175-189.

46. Nikolic, T., M.F. de Bruijn, M.B. Lutz, and P.J. Leenen. 2003. Developmental stages of myeloid dendritic cells in mouse bone marrow. Int. Immunol. 15:515-524.
47. Leon, B., G. Martinez del Hoyo, V. Parrillas, H.H. Vargas, P. SanchezMateos, N. Longo, M. Lopez-Bravo, and C. Ardavin. 2004. Dendritic cell differentiation potential of mouse monocytes: monocytes represent immediate precursors of CD8 - and CD8+ splenic dendritic cells. Blood. 103:2668-2676.

48. Drevets, D.A., M.J. Dillon, J.S. Schawang, N. Van Rooijen, J. Ehrchen, C. Sunderkotter, and P.J. Leenen. 2004. The Ly-6Chigh monocyte subpopulation transports Listeria monocytogenes into the brain during systemic infection of mice. J. Immunol. 172:4418-4424

49. Vazquez-Torres, A., J. Jones-Carson, A.J. Baumler, S. Falkow, R Valdivia, W. Brown, M. Le, R. Berggren, W.T. Parks, and F.C. Fang. 1999. Extraintestinal dissemination of Salmonella by CD18-expressing phagocytes. Nature. 401:804-808.

50. Cailhier, J.F., M. Partolina, S. Vuthoori, S. Wu, K. Ko, S. Watson, J. Savill, J. Hughes, and R.A. Lang. 2005. Conditional macrophage ablation demonstrates that resident macrophages initiate acute peritoneal inflammation. J. Immunol. 174:2336-2342.

51. Bakri, Y., S. Sarrazin, U.P. Mayer, S. Tillmanns, C. Nerlov, A. Boned, and M.H. Sieweke. 2005. Balance of MafB and PU.1 specifies alternative macrophage or dendritic cell fate. Blood. 105:2707-2716.

52. Aliberti, J., O. Schulz, D.J. Pennington, H. Tsujimura, C. Reis e Sousa, K. Ozato, and A. Sher. 2003. Essential role for ICSBP in the in vivo development of murine CD8alpha+ dendritic cells. Blood. 101:305-310.

53. Ichikawa, E., S. Hida, Y. Omatsu, S. Shimoyama, K. Takahara, S. Miyagawa, K. Inaba, and S. Taki. 2004. Defective development of splenic and epidermal CD4+ dendritic cells in mice deficient for IFN regulatory factor-2. Proc. Natl. Acad. Sci. USA. 101:3909-3914.

54. Lu, R., and P.M. Pitha. 2001. Monocyte differentiation to macrophage requires interferon regulatory factor 7. J. Biol. Chem. 276:45491-45496.

55. Colvin, G.A., J.F. Lambert, M. Abedi, C.C. Hsieh, J.E. Carlson, F.M. Stewart, and P.J. Quesenberry. 2004. Murine marrow cellularity and the concept of stem cell competition: geographic and quantitative determinants in stem cell biology. Leukemia. 18:575-583.

56. Landsman, L., C. Varol, and S. Jung. 2007. Distinct differentiation potential of blood monocyte subsets in the lung. J. Immunol. In press. 